\title{
Studi Gambaran Histopatologi Hepar Tikus Putih Strain Wistar yang Diinduksi Aspirin Pascapemberian Ekstrak Etanol Umbi Iles-iles (Amorphophallus variabilis Bl.) Selama 7 Hari
}

\author{
Arfatul Makiyah, ${ }^{1}$ Lela Laelatul Khumaisah ${ }^{2}$ \\ ${ }^{1}$ Program Studi D3 Keperawatan Universitas Muhammadiyah Sukabumi, Indonesia \\ ${ }^{2}$ Program Studi Kimia Universitas Muhammadiyah Sukabumi, Indonesia
}

\begin{abstract}
Abstrak
Paradigma yang berkembang di masyarakat kita saat ini ramuan tradisional dikarenakan bahan-bahannya berasal dari alam adalah tidak berbahaya dan tidak mempunyai efek samping. Tujuan penelitian adalah mengetahui gambaran histopatologi hepar tikus putih strain Wistar yang diinduksi aspirin pasca pemberian ekstrak umbi iles-iles (Amorphophallus variabilis Bl.). Penelitian ini dilaksanakan di Laboratorium Farmakologi Universitas Padjadjaran pada bulan April-Mei 2018. Tikus putih strain Wistar sebanyak 20 ekor dibagi menjadi 4 kelompok. Tikus putih strain wistar pada setiap perlakuan diberikan ekstrak iles-iles secara oral selama 7 hari pada tanggal 8-14 April 2018. Parameter gambaran histopatologi hepar tikus putih strain wistar yang diinduksi aspirin pascapemberian ekstrak umbi iles-iles (Amorphophallus variabilis $\mathrm{Bl}$.) dengan dosis yang berbeda (0 mg/ $\mathrm{kgBB}, 220 \mathrm{mg} / \mathrm{kgBB}, 110 \mathrm{mg} / \mathrm{kgBB}, 55 \mathrm{mg} / \mathrm{kgBB}$ ) adalah preparat histopatologi hepar masing-masing dilakukan 5 lapang pandang mikroskopik. Hasil penelitian hasil Uji Kruskall Wallis menunjukkan bahwa kelompok tikus putih strain Wistar yang diberi ekstrak dengan dosis masing-masing 110 dan $220 \mathrm{mg} / \mathrm{kgBB}$ lebih banyak $(\mathrm{p}<0,05)$ tikus putih strain Wistar yang mengalami penebalan septa interalveolaris dibanding dengan kelompok I (kontrol). Pemberian ekstrak terstandar etanol umbi iles-iles dosis tunggal $110 \mathrm{mg} / \mathrm{kgBB}$ dan $220 \mathrm{mg} / \mathrm{kgBB}$ pada tikus putih strain Wistar tampak menimbulkan perubahan histopatologi berupa radang, nekrosis, kongesti, dan perlemakan hepar.
\end{abstract}

Kata kunci: Ekstrak Etanol, histopatologi, umbi Iles-iles (Amorphophallus variabilis Bl.)

\section{Liver Histopathological Features in White Wistar Rats Induced with Aspirin After 7 Days Administration of Ethanol Extract from Iles-iles Bulb (Amorphophallus variabilis Bl.)}

\begin{abstract}
The society currently has a paradigm that traditional medicine is safer because the ingredients come from nature, making them harmless and no side effects should be experienced. The aim of this study was to identify the histopathological features of aspirin-induced Wistar rats after the administration of iles-iles bulb extract (Amorphophallus variabilis $\mathrm{Bl}$.). This study was conducted at the Pharmacology Laboratory of Universitas Padjadjaran in April to May 2018. Twenty Wistar white rat strain were divided into 4 groups treated by 4 different doses of iles-iles extract i.e., 0, 55, 110, and $220 \mathrm{mg} / \mathrm{kg}$ BW. Wistar strain white rats on each treatment received iles-iles extract orally for 7 days during the period of 8 to14 of April 2018. The histopathological feature parameters of Wistar rats induced with aspirin after 7 days administrations of iles-iles extract (Amorphophallus variabilis Bl.) were then observed. Results based on analysis using Kruskall Wallis test showed that many rats in the groups treated by 110 and $220 \mathrm{mg} / \mathrm{kgBW}$ extract $(\mathrm{p}<0.05)$ presented thickened interalveolar septum when compared to group I (control). Provision of standardized ethanol extract of iles-iles tuber using a single dose of $110 \mathrm{mg} / \mathrm{kgBW}$ and $220 \mathrm{mg} / \mathrm{kgBW}$ in white mice of Wistar strains appears to cause histopathological changes such as inflammation, necrosis, congestion, and changes in hepatic fatty acids.
\end{abstract}

Key words: Ethanol extract, histopathology, iles-iles tubers (Amorphophallus variabilis $\mathrm{Bl}$.),

Korespondensi: Arfatul Makiyah, S.Pd., M.Kes, Prodi D-III Keperawatan Universitas Muhammadiyah Sukabumi, Jalan R. Syamsudin No. 50 Kota Sukabumi, Jawa Barat, Email: arfa.makiyah.spd.mkes@gmail.com; arfatul367@ummi.ac.id 


\section{Pendahuluan}

Iles-iles atau Amorphophallus variabilis BL tergolong marga Amorphophallus dan termasuk ke dalam suku talas-talasan (Araceae). Ilesiles adalah dua contoh bahan alam yang sudah diteliti memiliki khasiat sebagai zat anti radang, sehingga sampai saat ini sedang diteliti formulasi dan pembuatan sediaan campuran umbi iles-iles sebagai alternatif anti radang/inflamasi pada luka Penggunaan ekstrak umbi iles-iles sebagai antiradang/inflamasi harus diteliti lebih lanjut karena akan digunakan dalam jangka panjang. Selain itu, ekstrak umbi iles-iles juga harus lolos uji toksisitas akut, subkronik, dan kronik karena belum diketahui secara pasti ada atau tidaknya senyawa yang terkandung dalam ekstrak umbi iles-iles yang dapat menimbulkan efek samping ataupun perubahan fungsi organ. ${ }^{1}$

Tanaman umbi iles-iles merupakan salah satu tanaman yang digunakan sebagai obat alami. Umbi iles-iles berkhasiat sebagai obat bisul, luka iris, dan luka karena gigitan binatang berbisa. Umbi iles-iles memiliki kandungan kimia antara lain: air, glukomanan, saponin, flavonoid, pati, protein, lemak, serat kasar, dan kalsium oksalat. Sementara itu, daun iles-iles mengandung tanin. Kandungan kimia alami yang terdapat pada umbi iles-iles yang memiliki aktivitas anti-inflamasi dan memacu aktivitas makrofag sehingga meningkatkan sistem kekebalan tubuh antara lain adalah flavonoid, saponin, dan polisakarida. ${ }^{2}$

Mengingat pemanfaatannya yang cukup luas spektrumnya terutama pada penyakit infeksi sangat mungkin efek yang ditimbulkan adalah efek positif sebagai imunostimulator. Untuk menguji hal itu, penelitian dilakukan untuk melihat pengaruhnya pada peningkatan aktivitas dan kapasitas makrofag. Umbi iles-iles memiliki kandungan kimia, yaitu air, saponin, glukomanan, flavonoid, pati, protein, lemak, serat kasar, dan kalsium oksalat. Sementara itu, daun iles-iles memiliki kandungan kimia, yaitu tanin. Kandungan kimia alami yang terdapat pada umbi iles-iles yang diduga mempunyai aktivitas anti-inflamasi dan memacu aktivitas makrofag sehingga meningkatkan sistem kekebalan tubuh adalah flavonoid dan saponin. ${ }^{3}$

Beberapa penelitian mengenai khasiat ilesiles selain sebagai obat bisul, luka iris, dan juga luka karena gigitan binatang berbisa telah dilakukan, antara lain iles-iles diyakini mampu menormalkan kadar kolesterol, mencegah tekanan darah tinggi, dan menormalkan kadar gula darah. Penelitian serupa dilakukan juga pada ekstrak umbi iles-iles yang dipergunakan dalam medium pertumbuhan mikrob pengganti agar. Hasil penelitian lain juga menunjukkan bahwa ekstrak umbi iles-iles sebagai alternatif diversifikasi makanan diet bagi penderita diabetes melitus, didasarkan pada hasil penelitian Didah Nur Faridah staf pengajar Fakultas Teknologi Pertanian IPB yang menunjukkan bahwa umbi iles-iles (Amorphophallus) memiliki nilai Indeks glukomanan-nya (IG) cukup rendah, yaitu sebesar 42 sehingga,Iles-iles termasuk bahan pangan yang memiliki nilai IG rendah (kurang dari 55). ${ }^{4}$

Paradigma yang berkembang di masyarakat kita saat ini adalah bahwa ramuan tradisional dikarenakan bahan-bahannya berasal dari alam adalah tidak berbahaya dan tidak mempunyai efek samping. Anggapan itu tidak sepenuhnya benar sehingga dibutuhkan informasi yang menyampaikan tentang batas aman penggunaan obat tradisional. Salah satu tolok ukur awal yang diperlukan untuk mengevaluasi keamanan suatu obat (ramuan tradisional) adalah potensi ketoksikan akut obat atau ramuan tradisional terkait. $^{5}$

Aspirin merupakan salah satu jenis non steroid anti-inflammatory drugs atau (NSAIDs) yang banyak digunakan pada pengobatan nyeri ringan sampai sedang. Efek farmakologi aspirin antara lain analgesik, antipiretik, anti-inflamasi, serta anti koagulan. Apabila aspirin diberikan secara oral maka akan diabsorbsi dengan baik di usus halus, dihidrolisis dalam darah dan di jaringan menjadi asetat dan asam salisilat yang merupakan komponen aktif. Waktu yang diperlukan untuk dihidrolisis di hepar sehingga menjadi bentuk salisilat dalam plasma kira-kira 30 menit. $^{6}$

Selain mempunyai efek terapi, aspirin juga memiliki beberapa efek samping di antaranya nyeri abdominal, hipokalemia, hipoglikemia, pireksia, hiperventilasi, distrimia, hipotensi, halusinasi, gagal ginjal, koma, dan berakhir pada kematian jika overdosis. Selain itu, juga aspirin mempuyai efek toksisitas yang tinggi. ${ }^{6}$

Organ yang berperan sebagai detoksifikasi adalah hepar. Hepar merupakan kelenjar paling besar dalam tubuh yang mempunyai banyak fungsi termasuk memetabolisme obat. Hepar juga memiliki keterbatasan fungsi detoksifikasi sebagai efek overdosis zat toksik. Biasanya proses detoksifikasi dan beberapa komponen obat memproduksi komponen dengan toksisitas yang lebih tinggi dan sering bermanifestasi pada tempat sintesis komponen tersebut. Jika zat hepatotoksik melewati batas fisiologisnya maka akan terjadi patofisiologis, termasuk akibat zat 
aspirin. $^{6}$

Salah satu efek samping dari terapi aspirin adalah ulkus lambung sehingga dilakukan cara mencegah efek samping tersebut. Salah satu upaya yang dilakukan adalah pemberian ekstrak etanol umbi iles-iles sebelum diberikan aspirin. ${ }^{7}$ Ekstrak etanol umbi iles-iles dapat digunakan untuk pengobatan kasus hepatitis kronik karena ekstrak etanol umbi iles-iles meningkatkan persediaan glikogen hepar melalui peningkatan glukosa darah. Ekstrak etanol umbi iles-iles mempunyai kemampuan untuk mengeliminasi radikal bebas melalui reaksi reduksi dan juga konjugasi sehingga dapat digunakan sebagai protektor organ hepar akibat dari paparan radikal bebas. Ekstrak etanol umbi iles-iles sebagai obat dapat digunakan sebagai antibakteri, antidiare, meredakan alergi, kosmetika, antikanker, dan anti-hepatotoksik. ${ }^{8}$ Antioksidan yang dimiliki oleh ekstrak etanol umbi iles-iles seperti vitamin E dan beta karoten mampu melawan oksigen perusak khususnya radikal bebas dan peroksidasi lipid dalam jaringan. ${ }^{9}$

Sejauh mana pemberian ekstrak etanol umbi iles-iles dapat memproteksi hepar dari kejadian ulkus karena kemungkinan efek aspirin yang diberikan setelahnya. Menjawab hal tersebut maka perlu dilakukan penelitian.

\section{Metode}

Penelitian ini bersifat eksperimental laboratorik dengan desain post test only control group design. Penelitian ini menggunakan hewan coba tikus putih galur strain Wistar yang dibagi menjadi 4 kelompok perlakuan. Subjek penelitian adalah 20 ekor tikus putih (Rattus novergicus) strain Wistar yang diperoleh dari Laboratorium Biofarma Bandung. Penelitian ini dilakukan di Laboratorium Farmakologi Universitas Padjadjaran Bandung yang dilakukan pada bulan April 2018.

Sampel yang digunakan adalah 20 ekor tikus putih jantan galur Wistar (Rattus Norvegicus), umur 2 bulan dengan bobot \pm 200 gram. Bahan utama untuk perlakuan adalah aspirin. Bahan lain yang dipergunakan adalah kapas, alkohol, larutan netral bufer formalin 10\% untuk fikasasi, bahan pembuatan preparat histopatologi seperti alkohol, xylol, parafin, gliserin, dan pewarnaan hematoksilin eosin (HE). Kandang tikus berupa bak plastik bertutup kawat dan diberi alas serbuk gergaji serta dilengkapi dengan tempat makan dan minum, spuit injeksi, ember, alat bedah, tempat jaringan, tissue processor, mikroskop cahaya, mikrotom, waterbath, gelas objek, dan gelas penutup.

Sampel dibagi menjadi 4 kelompok, sehingga tiap-tiap kelompok berjumlah 5 ekor tikus. Perlakuan pada tiap-tiap kelompok adalah sebagai berikut: KK sebagai kelompok kontrol diberi akuades $1 \mathrm{~mL} / \mathrm{kgBB}$, sedangkan kelompok perlakuan (KP): KP1 diberi larutan ekstrak etanol umbi iles-iles dosis $220 \mathrm{mg} / \mathrm{kgBB}$; KP2 diberi larutan ekstrak etanol umbi iles-iles dosis 110 mg/kg BB; KP3 diberi larutan ekstrak etanol umbi iles-iles dosis $55 \mathrm{mg} / \mathrm{kgBB}$. Pemberian larutan ekstrak etanol umbi iles-iles dilakukan per oral, sekali setiap hari selama 7 hari. Pada hari ke-7 semua kelompok perlakuan diberikan aspirin $150 \mathrm{mg} / \mathrm{kg} \mathrm{BB}, 1$ jam pascapemberian. Lalu, pada hari ke-8 semua tikus percobaan dieutanasia dan dinekropsi. Hepar diambil dan diperiksa untuk selanjutnya diproses dalam pembuatan preparat histopatologis.

Organ hepar diambil dan dipotong menjadi ukuran 1x1x1 cm, kemudian difiksasi dalam NBF $10 \%$ selama 24 jam. Setelah di-streaming, kemudian dimasukkan ke dalam tissue cassette masing-masing sesuai kelompok perlakuan. Tissue cassette dimasukkan ke dalam tissue processor untuk tahap dehidrasi, clearing, dan embedding. Sementara itu, tahap bloking dilakukan dengan paraffin blok, selanjutnya cutting dengan mikrotom dalam ketebalan 5-6 $\mu$. Selanjutnya, preparat diwarnai dengan pewarnaan hematoksilin eosin (HE). Setelah dikeringkan dan ditutup dengan cover glas, preparat siap diperiksa di bawah mikroskop.

Bahan-bahan yang digunakan pada penelitian ini adalah: ekstrak etanol umbi iles-iles. Umbi iles-iles, hasil determinasi tanaman di Herbarium Bandungense, Sekolah Ilmu dan Teknologi Hayati ITB menyatakan bahwa tanaman tersebut adalah Amorphophallus variabilis Bl. dari suku Araceae. Umbi Iles-iles sebagai bahan uji diambil dari perkebunan di daerah Depok dan Majalengka, Jawa Barat. Umbi yang dipilih adalah umbi iles-iles dewasa yang siap panen, kemudian dilakukan ekstraksi di Laboratorium Farmasi, Institut Teknologi Bandung (ITB), akuades steril (akuabides), $\mathrm{NaCl}$ 0,9\% bebas pirogen, alkohol $70 \%$, dan metanol absolut. Larutan chloroform untuk eutanasi hewan uji coba, yaitu tikus putih strain Wistar.

Alat yang dipergunakan dalam penelitian ini adalah perangkat alat pengukur berat-: timbangan hewan, timbangan digital Agis (skala 0-2.000 gram) dengan ketelitian 0,01 gram. Peralatan adaptasi hewan coba: kandang tikus putih, tempat minum tikus putih, dan feeding 
tube FR-5. Peralatan alat pembuat ekstrak etanol umbi iles-iles: maserator, rotary evaporator, dan oven. Peralatan pemberian ekstrak etanol umbi iles-iles secara oral: penyuntikan secara oral 5 mL dengan jarum ukuran 18 gauge, dan botol untuk menyimpan dosis. Peralatan kultur in vivo tabung reaksi, mikro pipet (pipet eppendorf), dan pipet. Peralatan pemeriksaan fisik: peralatan bedah minor, erlenmeyer $500 \mathrm{~mL}$, tabung sampel darah eppendorf, serta spuit injeksi 1 cc, 3 cc, 5 cc, dan $10 \mathrm{cc}$. Peralatan pengamatan mikroskopis: cover glass dan object glass, minyak imersi, serta sentrifugator $2.500 \mathrm{rpm}$. Peralatan untuk pengamatan fisik dan mikroskopis adalah mikroskop cahaya (Olympus ${ }^{\circledR}$ ) BX61 dengan perbesaran 1.000x dan LCD Notebook. Peralatan dokumentasi: kamera digital.

Dosis ekstrak etanol umbi iles-iles ini didapatkan hasil konversi dosis yang lazim pada manusia dengan perhitungan sebagai berikut: bobot bersih simplisia umbi iles-iles 1.500 gram; Bobot bersih ekstrak etanol umbi iles-iles 41,6 gram ( $\pm 2 \%$ bobot simplisia); Dosis lazim simplisia pada manusia per hari adalah $3 \times 1$ sendok serbuk simplisia $=3 \times 10$ gram $=$ 30 g simplisia; Dosis ekstrak etanol umbi ilesiles pada manusia (70 kg) per hari $2 \%$ x $30 \mathrm{~g}$ simplisia ialah 0,6 g ekstrak etanol umbi iles-iles; Dosis ekstrak etanol umbi iles-iles pada tikus (200 mg) per hari ialah 0,018x0,6 gram $=0,0108$ gram $=10,8 \mathrm{mg} \approx 11 \mathrm{mg}=55 \mathrm{mg} / \mathrm{kgBB}$.

Dua puluh lima ekor tikus dibagi menjadi 4 kelompok perlakuan untuk melihat gambaran histopatologis hepar tikus putih strain Wistar yang diinduksi aspirin pascapemberian ekstrak etanol umbi iles-iles (Amorphophallus variabilis Bl.). Kemudian tikus diadaptasikan selama 7 hari dengan pemberian pelet agar tikus sehat. Kelompok perlakuan dilakukan selama 7 hari, untuk melihat gambaran histopatologis hepar tikus putih strain Wistar yang diinduksi aspirin pascapemberian ekstrak etanol umbi ilesiles (Amorphophallus variabilis Bl.) masingmasing perlakuan sebagai berikut: Kelompok I (kelompok kontrol dengan akuades); Kelompok II (ekstrak etanol umbi iles-iles dosis 220 mg/ kgBB); Kelompok III (ekstrak etanol umbi ilesiles dosis 110 mg/kgBB); Kelompok IV (ekstrak etanol umbi iles-iles dosis $55 \mathrm{mg} / \mathrm{kgBB}$ ).

Seri dosis ekstrak etanol umbi iles-iles dibuat dengan melarutkan sejumlah x mg ekstrak etanol umbi iles-iles ditambahkan pelarut (larutan akuades sebanyak $5 \mathrm{~mL}$ /ekor tikus putih strain Wistar). Akuades digunakan sebagai kontrol pelarut maupun kontrol normal. Pada hari ke-7 tikus disuntik oral secara intravena (i.v.) dengan ekstrak etanol dosis $55 \mathrm{mg} / \mathrm{kgBB}, 110 \mathrm{mg} / \mathrm{kgBB}$, dan $220 \mathrm{mg} / \mathrm{kgBB}$, kemudian dibiarkan dalam 30 menit, 4 jam, 24 jam, 48 jam, serta 1 minggu dan 2 minggu. Sediaan uji diberikan pada hewan coba secara oral, satu kali selama masa uji dengan sebelum perlakuan tikus putih strain Wistar ditimbang terlebih dahulu. Kemudian dilakukan pemberian aspirin $150 \mathrm{mg} / \mathrm{kgBB}$.

Pengamatan dilakukan secara terus menerus pada 30 menit pertama dan kemudian dilakukan setiap hari. Setelah hasil penelitian terkumpul, kemudian dilakukan pengolahan data dengan urutan sebagai berikut: preparat histopatologi hepar masing-masing dilakukan 5 lapang pandang mikroskopik, Perubahan histopatologi yang diamati berupa kongesti, infiltrasi sel radang, hemoragi, dan nekrosis, analisis awal dilakukan pengujian distribusi data. Dilakukan analisis data menggunakan data yang diperoleh dari hasil pengamatan histopatologi hati dipersentasekan dan dianalisis secara statistik menggunakan analisis varian dan dilanjutkan dengan uji statistik nonparametrik Kruskal Wallis untuk melihat ada tidaknya perbedaan efek perlakuan yang diberikan antara kelompok tikus putih strain Wistar yang diberikan perlakuan terhadap tikus putih strain Wistar kontrol taraf signifikansi 5\% (p<0,05). Untuk melengkapi hasil perbandingan antara kelima kelompok pengamatan, dibuat penggambaran grafik ke dalam diagram batang dan rerata setiap variabel.

Hewan coba yang digunakan pada penelitian ini adalah tikus putih galur strain Wistar untuk menggantikan manusia sebab zat atau alat baru tidak boleh digunakan untuk pertama kali pada manusia, kecuali bila sebelumnya telah diuji pada hewan dan diperoleh kesan yang cukup mengenai keamanannya. ${ }^{10}$

\section{Hasil}

Subjek penelitian terdiri atas 20 ekor tikus strain Wistar yang telah melewati masa adaptasi di laboratorium selama tujuh hari, memenuhi kriteria inklusi, dan tidak memenuhi kriteria eksklusi. Hasil penelitian gambaran histopatologis hepar tikus putih strain Wistar yang diinduksi aspirin pascapemberian ekstrak etanol umbi iles-iles (Amorphophallus variabilis Bl.) dilakukan membandingkan dengan kontrol akuades. Setelah hasil penelitian terkumpul, dilakukan pengolahan data dengan analisis awal pengujian distribusi data, kemudian data yang diperoleh dari hasil pengamatan histopatologi 


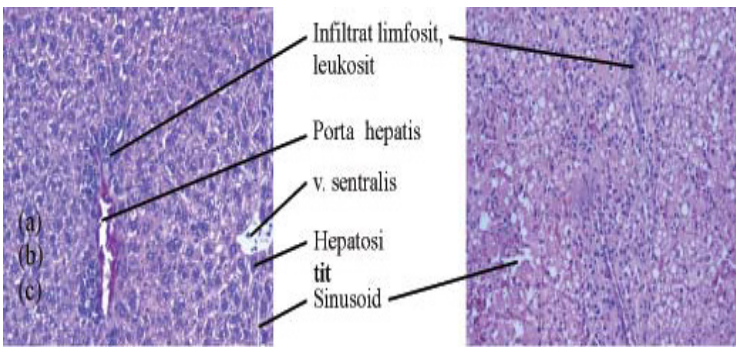

(1)

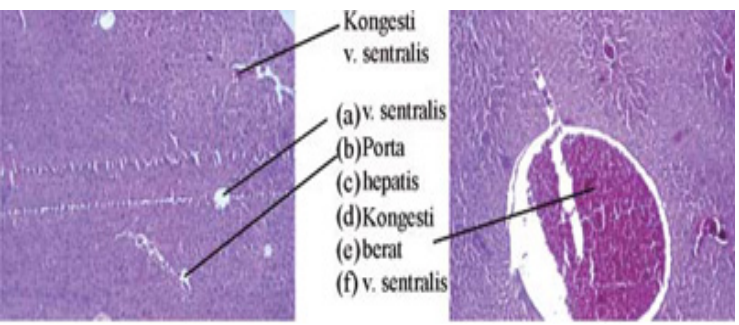

(3)
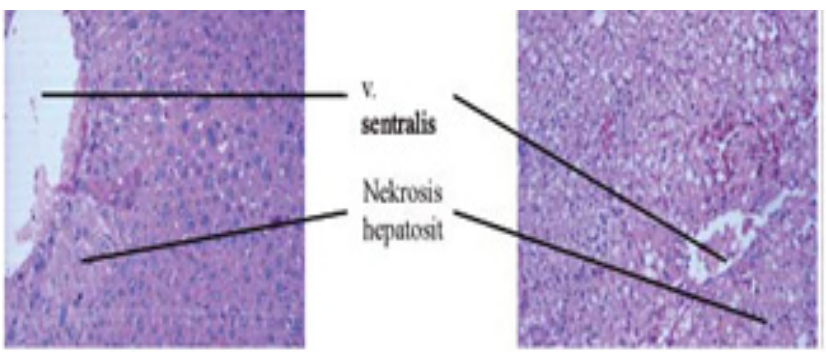

(2)

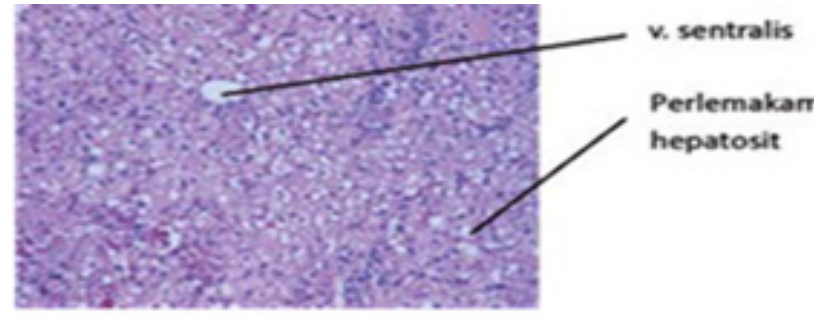

(4)

\section{Gambar 1 Gambaran Mikroskopis Hepar Tikus Putih Strain Wistar Pascapemberian Ekstrak Etanol Umbi Iles-iles yang Diinduksi Aspirin $150 \mathrm{mg} / \mathrm{kg}$ BB}

\section{Keterangan :}

(1.) Hepar tikus putih strain Wistar pascapemberian ekstrak etanol umbi iles-iles yang diinduksi aspirin $150 \mathrm{mg} / \mathrm{kg}$ BB yang mengalami radang ringan. Infiltrat sel radang terlokalisasi di sekitar porta hepatis (a). Tikus yang diberi iles-iles dosis $55 \mathrm{mg} / \mathrm{kg} \mathrm{BB}$, mengalami radang berat. Infiltrat sel radang tersebar dari porta hepatis sampai vena sentralis (b). Pembesaran 100x, Pewarnaan hematoksilin eosin.

(2). Hepar tikus putih strain Wistar pascapemberian ekstrak etanol umbi iles-iles yang diinduksi aspirin $150 \mathrm{mg} / \mathrm{kg} \mathrm{BB}$ menunjukkan radang ringan, nekrosis terjadi di area asiner 3 atau terdekat dengan vena sentralis (a). Tikus yang diberi iles-iles dosis $55 \mathrm{mg} / \mathrm{kgBB}$ menunjukkan nekrosis berat, yang terjadi secara mengelompok dan atau difus pada hepar (b). Pembesaran 100x, pewarnaan hematoksilin eosin. (3.) Hepar tikus putih strain Wistar pascapemberian ekstrak etanol umbi iles-iles yang diinduksi aspirin $150 \mathrm{mg} / \mathrm{kg}$ BB yang mengalami kongesti ringan. Pelebaran pembuluh darah ringan yaitu kondisi pembuluh nadi mengalami pelebaran dikarenakan melemahnya pembuluh darah dalam sinusoid hepar (a). Tikus yang diberi $220 \mathrm{mg} / \mathrm{kgBB}$ mengalami kongesti berat, tampak pelebaran pembuluh darah dan perdarahan berlebihan $(>50 \%)$ dalam sinusoid hepar (b). Pembesaran $40 \mathrm{x}$, pewarnaan hematoksilin eosin.

(4.) Hepar tikus putih strain Wistar pascapemberian ekstrak etanol umbi iles-iles yang diinduksi aspirin $150 \mathrm{mg} / \mathrm{kgBB}$ mengalami perlemakan, tampak sebagai vakuola-vakuola kosong pada sitoplasma sel hepar. Pembesaran 100x, pewarnaan Hematoksilin Eosin.

hati dipersentasekan serta dianalisis secara statistik mempergunakan analisis varian dan dilanjutkan dengan uji statistik nonparametrik Kruskal Wallis untuk melihat ada tidaknya perbedaan efek perlakuan yang diberikan antara kelompok kontrol positif dan kelompok kontrol negatif. Untuk melengkapi hasil perbandingan antara kelima kelompok pengamatan dibuat penggambaran grafis ke dalam diagram batang dan rerata setiap variabel.

Hasil penelitian tentang studi histopatologi hepar tikus putih strain Wistar yang diinduksi aspirin pascapemberian ekstrak etanol umbi iles-iles (Amorphophallus variabilis Bl.). Kadar aspirin pada kelompok tikus putih strain Wistar yaitu $150 \mathrm{mg} / \mathrm{kgBB}$ sama dengan dengan kelompok tikus normal yang mempunyai kadar aspirin $150 \mathrm{mg} / \mathrm{kgBB}$. Keadaan ini sesuai dengan penelitian yang dilakukan oleh Sudrajat bahwa aspirin dapat meningkatkan kadar trigliserida dalam darah.

Perubahan gambaran histopatologi hepar setelah pemberian ekstrak etanol umbi ilesiles adalah radang, kongesti, dan nekrosis, serta perlemakan. Radang pada hepar telah memperlihatkan infiltrat limfosit dan leukosit polimorfonuklear yang terlokalisasi di sekitar vena porta hepar tikus menunjukkan radang hepar ringan, yaitu kondisi penyakit dan infeksi yang memengaruhi sel, jaringan, struktur, dan 
Arfatul Makiyah dkk.: Studi Gambaran Histopatologi Hepar Tikus Putih Strain Wistar yang Diinduksi Aspirin Pascapemberian Ekstrak Etanol Umbi Iles-iles (Amorphophallus variabilis Bl.) Selama 7 Hari

Tabel 1 Hasil Pemeriksaan Hepar Tikus Putih Strain Wistar yang Diinduksi Aspirin Setelah Pemberian Ekstrak Terstandar Etanol Umbi Iles-Iles Sebagai Dosis Tunggal

\begin{tabular}{|c|c|c|c|c|c|c|c|c|c|c|c|}
\hline \multirow{2}{*}{$\begin{array}{c}\text { Kelompok } \\
\text { \& Dosis } \\
\text { (mg/kgBB) }\end{array}$} & \multicolumn{3}{|c|}{ Derajat Radang (\%) } & \multicolumn{3}{|c|}{ Derajat Nekrosis (\%) } & \multicolumn{3}{|c|}{ Derajat Kongesti (\%) } & \multicolumn{2}{|c|}{$\begin{array}{c}\text { Perlemakan } \\
(\%)\end{array}$} \\
\hline & $\begin{array}{c}\text { Tidak } \\
\text { Ada }\end{array}$ & Ringan & Berat & $\begin{array}{c}\text { Tidak } \\
\text { Ada }\end{array}$ & Ringan & Berat & $\begin{array}{c}\text { Tidak } \\
\text { Ada }\end{array}$ & Ringan & Berat & $\begin{array}{c}\text { Tidak } \\
\text { Ada }\end{array}$ & Ada \\
\hline$I(0)$ & 31 & 50 & 18 & 82 & 18 & 0 & 100 & 0 & 0 & 100 & 0 \\
\hline II (220) & 0 & 60 & 40 & 0 & 10 & 90 & 0 & 30 & 70 & 20 & $80^{*}$ \\
\hline III (110) & 0 & 85 & 15 & 14 & 72 & 14 & 55 & 31 & 14 & 12 & $88^{*}$ \\
\hline IV (55) & 0 & 61 & 39 & 61 & 0 & 39 & 59 & 12 & 29 & 61 & 39 \\
\hline
\end{tabular}

* $\mathrm{P}<0,05$ dibandingkan dengan kontrol (Kelompok I)

fungsi dari hati (Gambar 1a) maupun tersebar merata dari vena porta sampai ke vena sentralis yang menunjukkan radang hepar berat (Gambar 1b).

Pada pengamatan kualitatif terhadap nekrosis hepar yang telah memperlihatkan daerah yang mengalami kematian jaringan di daerah asiner 3 atau daerah terdekat vena sentralis yang menunjukkan nekrosis hepar ringan, yaitu tahap kematian sel pada jaringan hepar (Gambar 2a). Daerah yang mengalami kematian jaringan secara difusi dan atau mengelompok pada hepar menunjukkan nekrosis hepar berat (Gambar 2b).

Pada pengamatan kualitatif terhadap kongesti hepar telah memperlihatkan pelebaran pembuluh darah ringan, yaitu kondisi pembuluh nadi mengalami pelebaran secara abnormal disebabkan oleh melemahnya pembuluh darah di dalam sinusoid hepar yang menunjukkan kongesti hepar ringan, yaitu akumulasi abnormal secara berlebihan cairan tubuh (Gambar 3a). Pelebaran dan perdarahan berlebihan secara abnormal (>50\%) di dalam sinusoid hepar menunjukkan kongesti hepar berat, yaitu kondisi abnormal secara berlebihan dari cairan tubuh pada jaringan hepar (Gambar 3b). Pada pengamatan kualitatif perlemakan hepar telah memperlihatkan lemak pada jaringan hepar dalam bentuk vakuola lemak (Gambar 4).

Abnormalitas berupa radang, nekrosis, kongesti, dan perlemakan sudah mulai terlihat pada kelompok tikus putih yang diberi ekstrak etanol terstandar umbi iles-iles dengan dosis terendah $55 \mathrm{mg} / \mathrm{kg} \mathrm{BB}$, bahkan terjadi pada kelompok I (kontrol). Peningkatan dosis umbi iles-iles akan memengaruhi tingkat radang,

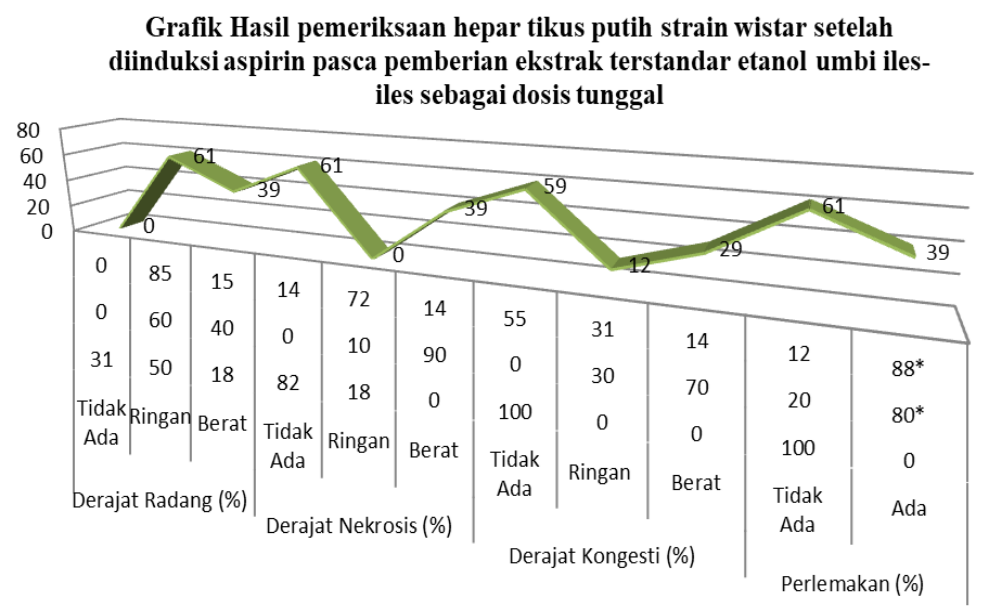

Gambar 2 Grafik Hasil Pemeriksaan Hepar Tikus Putih Strain Wistar Setelah Diinduksi Aspirin Pascapemberian Ekstrak Etanol Umbi Iles-Iles. Lesi yang Terjadi pada Tiap-tiap Kelompok Perlakuan. Tampak Kelompok Kontrol Sangat Dominan Mengalami Kongesti dan Peradangan. Secara Umum Lesi Kongesti Sangat Dominan Terjadi pada Semua Tikus Percobaan 
Tabel 2 Nilai Gambaran Histopatologi Hepar Tikus Putih Strain Wistar yang Diinduksi Aspirin Setelah Pemberian Ekstrak Terstandar Etanol Umbi Iles-Iles Sebagai Dosis Tunggal

\begin{tabular}{lcc}
\hline Kelompok Perlakuan & $\mathbf{n}$ & Nilai Parameter \\
\hline Tidak ada derajat radang & 5 & $(7,75 \pm 15,50)$ \\
Derajat radang ringan & 5 & $(64,0 \pm 14,85)$ \\
Derajat radang berat & 5 & $(28,0 \pm 13,34)$ \\
Tidak ada derajat nekrosis & 5 & $(39,25 \pm 38,63)$ \\
Derajat nekrosis ringan & 5 & $(25,0 \pm 32,18)$ \\
Derajat nekrosis berat & 5 & $(35,7 \pm 39,60)$ \\
Tidak ada derajat kongesti & 5 & $(53,50 \pm 41,05)$ \\
Derajat kongesti ringan & 5 & $(18,25 \pm 14,97)$ \\
Derajat kongesti berat & 5 & $(28,25 \pm 30,24)$ \\
Tidak ada perlemakan & 5 & $(48,25 \pm 40,63)$ \\
Ada perlemakan & 5 & $(51,75 \pm 40,63)$ \\
\hline
\end{tabular}

nekrosis, kongesti, dan perlemakan pada hepar. Semakin tinggi dosis, semakin tinggi persentase abnormalitas histopatologi hepar derajat berat yang terjadi. Penurunan dosis diikuti dengan penurunan persentase abnormalitas histopatologi hepar. Kelompok II dan III yang diberi ekstrak $220 \mathrm{mg} / \mathrm{kgBB}$ dan $110 \mathrm{mg} /$ kgBB memperlihatkan perubahan gambaran histopatologi derajat berat terbanyak dibanding dengan kelompok lainnya. Pada kelompok IV, $30 \%$ tikus putih strain Wistar mengalami radang berat dan sisanya mengalami radang ringan. Penurunan dosis diikuti dengan penurunan persentase radang berat dan ringan pada hepar (Tabel 1).

Perubahan nekrosis pada hepatosit juga terjadi pada tikus putih kelompok dosis I (220 $\mathrm{mg} / \mathrm{kgBB}$ ) sampai dosis III (55 mg/kgBB). Semakin tinggi dosis, semakin banyak tikus putih strain Wistar dengan nekrosis berat. Pada kelompok III, 50\% tikus putih strain Wistar mengalami nekrosis berat dan pada kelompok II, 90\% tikus putih strain Wistar mengalami nekrosis berat. Penurunan dosis diikuti dengan penurunan persentase nekrosis berat dan ringan pada hepar (Tabel 2).

Dari hasil penelitian didapatkan gambaran kongesti pada sinusoid hepar yang biasanya terjadi pada area sentralis. Perubahan kongesti pada hepatosit juga terjadi pada tikus putih strain Wistar kelompok dosis I (220 mg/kgBB) sampai dosis III ( $55 \mathrm{mg} / \mathrm{kgBB}$ ). Semakin tinggi dosis, semakin banyak tikus putih strain Wistar dengan kongesti berat. Pada kelompok II, 40\% tikus putih strain Wistar mengalami kongesti berat dan pada kelompok III, 70\% tikus putih strain Wistar mengalami kongesti berat. Penurunan dosis diikuti dengan penurunan persentase kongesti berat dan ringan pada hepar (Tabel 2).

Perlemakan hepar juga terjadi pada tikus putih strain Wistar kelompok dosis I (220 mg/ kgBB) sampai dosis III (55 mg/kgBB). Hasil Kruskall wallis menunjukkan bahwa tikus putih strain Wistar yang mengalami perlemakan hepar pada kelompok II, III, dan IV yang diberi ekstrak masing-masing $220 \mathrm{mg} / \mathrm{kgBB}, 110 \mathrm{mg} /$ $\mathrm{kgBB}$, dan $55 \mathrm{mg} / \mathrm{kgBB}$ lebih banyak $(\mathrm{p}<0,05)$ dibanding dengan kelompok kontrol.

\section{Pembahasan}

Pada hepar, pemberian ekstrak etanol umbi iles-iles dapat mengakibatkan reaksi radang ringan dan berat pada hepar mencit. Radang merupakan reaksi jaringan hidup terhadap semua bentuk jejas. Jejas pada proses toksik terjadi karena reaksi antara zat beracun dan molekul pada tubuh baik subseluler maupun seluler. ${ }^{11}$ Semakin sedikit dosis yang diserap tubuh, kerusakan yang terjadi hanya terbatas dan masih dapat dikompensasi oleh sel sehat lainnya untuk dapat menjalankan fungsi normal organ. ${ }^{12}$ Pada radang hepar, konsep pembagian zona mikroskopis hepar sangat berperan di dalam mengintepretasikan hubungan efek toksik dengan pola peradangan. Hepar memiliki 3 zona, yaitu zona 1, zona yang terdekat dengan arteri hepatika dan vena porta, zona 2 , yaitu zona intermediet, dan zona 3, zona yang berbatasan dengan vena sentralis. ${ }^{13}$ Ketiga zona ini memiliki perbedaan di dalam aliran darah sinusoid, kandungan oksigen, dan aktivitas metabolik, serta enzim. ${ }^{14}$ Menurut heterogenitas hepatosit, 
sel-sel perilobuler (zona 1) merupakan sel pertama yang menerima darah masuk ke hepar dengan kandungan oksigen yang banyak (sekitar 9-13\% $\mathrm{O}_{2}$ ), sedangkan sel-sel sentrolobuler, sel penebalan septa interalveolaris paru juga terjadi pada kelompok semua kelompok tikus putih strain Wistar yang diberi ekstrak. ${ }^{15}$

Hasil Pearson Chi-Square Test menunjukkan bahwa kelompok tikus putih strain Wistar yang diberi ekstrak dengan dosis masing-masing 3.000 dan $15.000 \mathrm{mg} / \mathrm{kgBB}$ lebih banyak $(\mathrm{p}<0,05)$ tikus putih strain Wistar yang mengalami penebalan septa interalveolaris apabila dibanding dengan kelompok VI (kontrol). Terdekat dengan vena sentralis (zona 3) memiliki kandungan oksigen terkecil (sekitar 4-5\% $\mathrm{O}_{2}$ ).

Pada pemeriksaan mikroskopis didapatkan infiltrasi sel radang dimulai dari vena porta ke arah vena sentralis. Hal ini sesuai dengan konsep heterogenitas hepatosit di atas karena zona 1 (vena porta) merupakan daerah pertama darah masuk ke hepar sebagai daerah pertama yang memetabolisme zat toksik. Dengan demikian, sel-sel radang pun pertama-tama muncul pada daerah vena porta ini. Semakin lama paparan toksik terjadi maka infiltrasi sel radang akan difusi dan menyebar dari daerah porta ke daerah sentralis.

Hepatosit yang mengalami nekrosis tampak tanpa pulasan inti sel sehingga tampak pucat. Hasil penelitian menunjukkan nekrosis terjadi dimulai dari daerah sekitar vena sentralis (zona 3). Hal ini sesuai dengan konsep heterogenitas hepatosit dengan zona 3 (vena sentralis) merupakan daerah yang paling memiliki potensi iskemik dibanding dengan zona lainnya karena memiliki jaringan dengan oksigenasi terendah (sekitar 4-5\% $\mathrm{O}_{2}$ ). ${ }^{16}$ Oksigen ini diperlukan dalam metabolisme zat toksik sehingga bila oksigen yang tersedia sedikit, maka proses detoksifikasi terganggu dan berakibat terjadi akumulasi zat toksik serta terjadi kematian sel atau nekrosis pada daerah tersebut. ${ }^{17}$

Pada pemeriksaan mikroskopis juga telah ditunjukkan pelebaran pembuluh darah dan perdarahan dalam sinusoid hepar sehingga jaringan tampak lebih merah. Kongesti merupakan reaksi patologis sebagai salah satu manifestasi terjadi peradangan akibat jejas. ${ }^{18}$ Setelah jejas, terjadi dilatasi kapiler akibat rangsang vasodilator sehingga vaskularisasi pada lokasi jejas melebar dan berisi darah yang terbendung (kongesti). Pada kongesti akut, daerah yang mengalami bendungan terjadi pada area sentralis dan apabila kongesti berlangsung lama maka seluruh tepi lobulus mengalami bendungan disertai pelebaran sinusoid hepar yang berisi eritrosit. ${ }^{18}$

Perlemakan hepar itu ditunjukkan dengan vakuola-vakuola kosong beragam ukuran dalam sitoplasma hepar. Proses perlemakan ini bersifat reversible dan disebabkan oleh pengeluaran transfer lipid dari dalam sel terhambat dan ketidakseimbangan sintesis dan juga pelepasan trigliserida oleh sel parenkim ke sirkulasi. ${ }^{18}$ Perubahan ini dapat terjadi karena gangguan oksigenasi seperti gangguan pada aliran darah maupun intoksikasi pada hepar. ${ }^{19}$

Pada penelitian ini pemberian ekstrak yang terstandar etanol umbi iles-iles dosis tunggal $110 \mathrm{mg} / \mathrm{kgBB}$ dan $220 \mathrm{mg} / \mathrm{kgBB}$ pada tikus putih strain Wistar menimbulkan perubahan histopatologi berupa radang, nekrosis, kongesti, dan perlemakan hepar. Kelemahan penelitian ini adalah tidak terdeteksinya kondisi organorgan dalam tikus putih strain Wistar sebelum perlakuan sehingga tidak diketahui bagaimana histopatologinya.

Berdasarkan hasil dan pembahasan dapat diambil simpulan bahwa perubahan bobot tikus putih strain Wistar kontrol dan tikus putih strain Wistar yang diberikan perlakuan dari sebelum diberikan ekstrak dan 14 hari setelahnya tidak terjadi perbedaan. Ada peran ekstrak etanol umbi iles-iles sebagai barier pada mukosa lambung dan usus terhadap efek samping aspirin sebagai zat hepatotoksik. Pemberian ekstrak etanol umbi iles-iles mampu mencegah kerusakan gambaran histopatologis hati tikus yang diinduksi aspirin pada dosis $150 \mathrm{mg} / \mathrm{kgBB}$.

\section{Daftar Pustaka}

1. Aggarwal S, Moodley YP, Thompson PJ, Misso NL. Prostaglandin $E_{2}$ and cysteinyl leukotriene concentrations in sputum: association with asthma severity and Eosinophilic Inflammation. Clin Exp Allergy. 2010;40(1):85-93.

2. Deora PS, Mishra CK, Mavani P, Asha R, Shrivastava B, Rajesh KN. Effective alternative methods of $\mathrm{LD}_{50}$ help to save number of experimental animals. J Chem Pharm Res. 2010;2(6):450-3.

3. Khan A, Rahman M, Islam MS. Antibacterial, antifungal and cytotoxic activities of amblyone isolated from Amorphophallus campanulatus. Indian J Pharmacol. 2008; 40(1):41-4.

4. Baratawidjaja KG, Iris Rengganis. Sel-sel sistem imun nonspesifik, sistem fagosit 
makrofag. Dalam: Wachjuni, Ambara, Prasna P, Farah P, penyunting. Imunologi dasar. Edisi ke-9. Jakarta: Balai Penerbit FKUI; 2010. hlm. 57-90.

5. Arfatul Makiyah, Usep Abdullah Husin, Ramlan Sadeli. Efek imunostimulasi ekstrak etanol umbi iles-iles terhadap aktivitas fagositosis sel makrofag pada tikus putih strain wistaryang diinokulasi staphylococcus aureus. MKB. 2016;48(2):68-77.

6. Arfatul Makiyah, Sumirat Tresnayanti. Uji toksisitas akut yang diukur dengan penentuan $\mathrm{LD}_{50}$ ekstrak etanol umbi iles-iles (amorphophallus variabilis bl.) terhadap tikus putih strain wistar. MKB. 2017;49(3):145-55.

7. Franca EL, Maynie JC, Correa VC, Pereira UCR, Batalini C, Ferrari CKB, dkk. Immunomodulatory effects of herbal plants plus melatonin on human blood phagocytes. Int J Phytomed. 2010;2(4):354-62.

8. Jain S, Dixit VK, Malviya N, Ambawatia V. Antioxidant, anti inflammation and hepatoprotective activity of etanolic and aqueous extracts of Amorphophallus campanulatus Roxb. tubers. Acta Pol Pharm. 2009;66(4):423-8.

9. Erkekoglu P, Giray BK, Basaran N.3R principle and alternative toxicity testing methods. FABAD J Pharm Sci. 2011;36(1):101-7.

10. Deshmukh NS, Bagchi M, Yasmin T, Bagchi D. Safety of a novel calcium/potassium saltof (-)-hydroxycitric acid (HCA-SX): II developmental toxicity study in rats. Toxicol Mech Methods. 2008;18(5):443-51.

11. Amanda Krysanti, Simon Bambang Widjanarko. Toksisitas subakut tepung glukomanan (A. muelleri Blume) terhadap SGOT dan natrium tikus Wistar secara in vivo.
Jurnal Pangan Agroindustri. 2014;2(1):1-7.

12. Lalitha P, Sripathi SK, Jayanthi P. Acute toxicity of extracts of Eichhornia crassipes (MART) solms. Asian J Pharm Clin Res. 2012;5(4):59-61.

13. Chaudhari SY, Nariya MB, Galib R, Prajapati PK. Acute and subchronic toxicity study of Tamra Bhasma (incinerated copper) prepared with and without Amritikarana. J Ayurveda Integr Med. 2016;7(1):23-9.

14. Katzung and Trevor. Pharmakology: A Riview Alih Bahasa Staf Pengajar Laboratorium Farmakologi, Fakultas Kedokteran Universitas Sriwijaya. Cetakan I. Jakarta: EGC Penerbit Buku Kedokteran. 1994.

15. Hartati S, Slamet R, Irkham W. Studi gambaran histopatologis hepar, pulmo, lien dan otak serta uji serologis pada tikus (Rattus norvegicus) yang diinfeksi Toxoplasma gondii. J Sain Veteriner 2017;35(1):9-15.

16. Fahmi M, Yudha F, Dwinna A. Gambaran histopatologis hati tikus (rattus novergicus) yang diinfeksi Trypanosoma evansi setelah pemberian ekstrak kulit batang jaloh (Salix tetrasperma Roxb). J Medika Veterinaria. 2015;9(2):141-5.

17. Pradhan SN, Meickel RP, Dutta SN .Pharmacology in Medicine: Principles and Practice. USA: SP Press International Inc; 1993.

18. Francisco J.S, Waldo L, Garcia J, Isadora L, Karin S. Histopathological and immunohistochemical characterisation of hepatic granulomas in Leishmania donovaniinfected BALB/c mice:a time-course study. Parasites Vector J. 2018;11(73):1-9.

19. Sherlock S. Penyakit hati dan saliran empedu, cetakan kedua. Jakarta: PT. Arkans, 2004. 